\title{
Attributes of Leadership Effectiveness in West Africa
}

\author{
Cynthia A. Bulley, Central University, Ghana \\ Noble Osei-Bonsu, Central University, Ghana \\ Hassan Adedoyin Rasaq, Lagos State University, Nigeria
}

\section{Introduction}

Diverse culture and its influences across the West African sub-region challenge leadership effectiveness. The aim of this paper is to examine the perceptions of leadership effectiveness in two West African countries. The concept of leadership in Ghana and Nigeria provides a telescopic view important to managers and international business organizations. This paper focuses on the defining variables and characteristics of interest and outlines the results of the country studies. Based on an in-depth qualitative study, the results are discussed focusing on the idiosyncrasies of culture, traditions, and leadership. The findings indicate that culture influences leadership effectiveness, and it is intrinsically linked to employee performance. In addition, spirituality and belief in deity were found to be a major influence on cultural beliefs which, in turn, influence leadership perception and expected leadership characteristics. Thus, a lens is provided for developing specific directed training and learning aids for organizations.

The West African sub-region is made up of sixteen countries. ${ }^{1}$ These countries' population and people adhere to various religious practices ${ }^{2}$ in addition to traditional African religions. The traditional African religions are spiritual yet intrinsically linked to the social and cultural practices of its people. The traditions and cultural legacy of the people are so deeply felt that they permeate all activities. Culture and leadership are recognized as an indispensable part of their lives. Culture is socially transmitted and forms the totality of the people's patterns of behavior, religion, customs, and traditions, and it is the essential root of behavior and components of social organization. Leadership is also structured according to the traditions and customs where authority is derived from the chief, genealogical lineage, or religious leaders. As a result, the leaders are deemed to be imbued with wisdom, authority and strength. These key elements and concepts of leadership transcend to current management styles and practices. In this article, the concept of leadership in the West-African sub-region is examined to determine the defining characteristics and variables. Culture, traditions, and its dimensions facilitate the review of participants' view of leadership. In the following discussion, the literature on dimensions of culture and leadership in West Africa are considered, followed by the results of the LEAD project.

\section{Culture and the Concept of Leadership in West' Africa}

Leadership is one of the most important concepts that have attracted global attention over the past decades; however, it has been conceptualized differently in different cultures. According to House et al. (2004), leadership is "the ability of an individual to influence, motivate, and enable others to contribute toward the effectiveness and success of the organizations of which they are members" (p. 15). In West Africa, specifically Ghana and Nigeria, the concept of leadership is partly a function of the traditions and cultural values of the people. By implication, an individual's perception and understanding of leadership may be influenced by the cultural setting in which they find themselves. The process of socialization plays a significant role in this regard. For instance, while growing up in a typically traditional environment, one is socialized to respect elderly people and community leaders. In addition, a child is not supposed to correct an elderly person even when they are wrong. This social arrangement tends to leave an impression on people about the infallibility and sacrosanctity of the elderly, who are regarded as the leaders of the community. This is consistent with the traditional chieftaincy system. West Africans accord traditional leaders (in some parts of Nigeria - Igwe, Oba - and other parts of Ghana - Nana, Togbe) reverence because they are regarded as fathers and custodians of the communities they rule. It is commonly thought that the paternalistic and non-egalitarian nature of traditional rule has found expression in the leadership styles adopted by managers in organizations and this is generally seen as effective by subordinates. 
Another major contributory factor has to do with the patriarchal nature of most West African communities. Traditional societies are characterized by male control and dominance in all spheres of life coupled with the marriage philosophy that the man must be the head of the family. The fact that there are few women in commercial organizations is considered a demonstration of patriarchy (Suleiman, 2010). Again, other authors posit that access of women to leadership positions is constrained by gender roles (Olojede, 2004). This perhaps creates a perception of the masculine characteristics associated with the concept of leadership among traditional West Africans. However, Nigeria is perceived to be a more masculine society compared to Ghana.

The dynamics of leadership is a function of the characteristics that pertain in the society or group. This is evident in the collectivist nature of West Africans (Hofstede, 2015). Both Nigerian and Ghanaian societies are characterized by high power distance which means that subordinates expect and accept the unequal distribution or hierarchical order of power and hence see an ideal leader as someone who must instruct them. Some studies have concluded that in Ghana, for example, a leader or manager who often seeks the opinion of his subordinates is likely to be seen as weak and incapable (Zoogah \& Beugré, 2013). On the other hand, a great leader is someone who acts as a superior father figure and makes all the important decisions. Similarly, many Nigerian employees think that leadership refers only to the leader, leading to a premature conclusion that they should be blamed for any failure especially in organizations (Chukwu \& Eluka, 2013). Thus the leadership style adopted by most Nigerian business leaders is pre-dominantly characterized by its task-oriented nature geared towards high job performance resulting in low job satisfaction among subordinates (Ogbeidi, 2012).

\section{The Current Research}

Qualitative methods were used to explore the attributes of leadership effectiveness in Ghana and Nigeria. This consisted of the Delphi Technique and focus group discussions as well as interviews with three insiders (Nigerians in leadership positions in Nigerian organizations) and three outsiders (foreign executives in leadership positions in Nigerian organizations). In Ghana, the study was carried out using six participants in the Delphi Technique and seven (five female, two male) in the focus group.

Responses to the question of ethnic or cultural background indicated that the most important response for Ghana was religious beliefs/love of God and tradition, beliefs, and cultural practices; for Nigeria, the cultural beliefs of ancestors and community views on moral behavior was highly valued. The belief in a deity which engenders moral cultural practices is common to both countries and to a large extent, representative of what characterizes the West African sub-region. In both countries, effective leaders were described in terms that reflect the broader leadership literature - achievement and results oriented, focused, committed, and hard-working. Integrity and courage were also seen as important. Some characteristics that might be seen as reflecting West African values include masculinity, the importance of religion and spirituality, and having a sense of humor. Nigerian responses included education and knowledge, honesty, trustworthy, fair, persevering and sociable. The findings also show that in Nigeria, leaders are classified as heroes and celebrated when they show concern for the needs and wellbeing of people in the face of challenges and life threatening circumstances. Further, Nigerian leaders who receive fair treatment and are well remunerated are seen as being motivated to work hard. Overall, for those in leadership positions and their subordinates, extrinsic rewards, recognition, a sense of pride, a sense of belonging and power tend to be motivators. The results suggest that Ghanaian leaders adopt both participatory and authoritarian styles; however, the authoritarian style is predominant (consistent with findings from Hofstede, 2001, and the GLOBE project, 2004). The description of Ghanaian employees as submissive and obedient coupled with the culture of high power distance have contributed to shaping the authoritarian style of leaders in organizations. The respondents' view of the best leadership approach for managers is to use engagement and employee involvement strategies. Nigerian leadership style is more participatory/democratic, but there are some notable exceptions of autocracy, which almost amounts to dictatorship. In addition, Nigerian leadership is often power-driven, based on status, with little regard for skills and merit.

These results have some lessons for business leaders in West Africa. Primarily, the belief in deities, moral values, and traditional practices influence the cultural and ethnic orientations of most West Africans. Spirituality and religious considerations may generally have positive implications; however there may be a negative side to this. For example, when faced with job challenges, individuals can be quick to make external attributions for their failure instead of looking for practical solutions to address the issue (Asiedu-Appiah et al., 2017; Hassan \& Lituchy, 2017). It is important for organizational leaders, especially "outsiders," to understand the culture and traditions of their employees and respect the culture and taboos of the people, while developing strategies that promote positive work attitudes. It was also observed that some local leaders are sometimes not confident enough to point out mistakes or sanction subordinates - unlike their foreign counterparts (Asiedu-Appiah et al., 2017). In this regard, local leaders should be encouraged to build their leadership capacity, including respect for time and participatory management approaches to enable 
Table 1: Leadership Characteristics found in Ghana and Nigeria from LEAD Responses

\begin{tabular}{|c|c|c|}
\hline Defining Variable & Ghana & Nigeria \\
\hline Culture and Leadership & Interlinked & Interlinked \\
\hline Role of Culture and Leadership Effectiveness & Significant degree of convergence & Significant degree of convergence \\
\hline Leadership Structure & Patriarchal (male dominated) & Patriarchal (male dominated) \\
\hline Leadership Effectiveness & $\begin{array}{c}\text { Results-oriented, committed, } \\
\text { courageous, hardworking and integrity }\end{array}$ & $\begin{array}{c}\text { Educated, knowledgeable, } \\
\text { trustworthy, sociable and persevering }\end{array}$ \\
\hline Leadership Style & Mixed (participatory and authoritarian) & Participatory/Democratic with exceptions of autocracy \\
\hline Indigenous Leadership Practices and Concepts & $\begin{array}{c}\text { Adopts paternalistic, non-egalitarian nature of leader- } \\
\text { ship influenced by traditional chieftaincy system }\end{array}$ & $\begin{array}{c}\text { Adopts patriarchal leadership style } \\
\text { underpinned by belief in ancestors and } \\
\text { community landmarks on moralistic behavior }\end{array}$ \\
\hline
\end{tabular}

them to play effective supervisory roles. Finally, the concept of effective leadership is believed to hinge on inter-personal relationships with subordinates, honesty, fairness, and commitment to duty among others. The work environment within which the leader operates is also considered a major motivator for hard work and effective leadership. Taking cognizance of these issues, organizations can endeavor to create a congenial work environment so that both employees and leaders work effectively towards achievement of organizational goals.

\section{Conclusion and IImplications}

The West African sub-region has varied cultural practices that affect the concept of leadership. The defining variables and practices of leadership indicate traits and styles that go beyond Hofstede's cross-cultural theories of leadership. Table 1 summarizes the concept of leadership and the defining characteristics and variables.

The implication of this review brings in the question of inclusiveness as a leadership mantra to integrate diverse factors to the concept. Diversity theorists suggest a unique collaboration between what is known about leadership, leaders (traits and attributes), the country-specific environmental factors and intuitive practices in a dynamic way. Hence, there is an inherent need to reexamine the elements of effective leadership in Africa and elsewhere to include factors that create a brand and contextualized identity for corporate leadership and leadership in general. The "African brand" would include, for instance, leadership concepts that incorporate cultural diversity recognizing the potential challenge posed by the diverse customs and cultural practices. A strategy of harnessing what we have, including others and showcasing it in its own unique way is the way forward. To put it in marketing parlance, strategizing to include culture, traditions and leadership to develop the
"African leadership style" is the next level of studies. The African brand can foster development of training materials to enhance the skills of business leaders.

For future managers in Africa, the onus lies in their ability to appropriately incorporate traditional and cultural practices, recognize and professionally apply styles that lead to valuable contributions to organizational goals. Specifically, there should be a marriage of African perceptions and styles of leadership with those that promote the strengths and goals of business entities. There is therefore the need to optimize the diverse concepts and practices of leadership in Africa and that which upholds organizational success for effective demonstration of corporate leadership and leadership in general. 


\section{Endnotes}

1 Benin, Burkina Faso, Cape Verde, Gambia, Ghana, Guinea, Guinea-Bissau, Cote D'lvoire, Liberia, Mali, Mauritania, Niger, Nigeria, Senegal, Sierra Leone, and Togo.

${ }^{2}$ In Africa as a whole, Christianity (62.9\%), Islam (30.2\%), and other faiths (6.9\%), according to The Future of World Religions: Religious Population Growth Projections in Sub-Saharan Africa, 2010-2050 (Pew Research Center, March 27, 2015).

\section{References}

Asiedu-Appiah, F., Agyapong, A., \& Lituchy, T. R. 2017. Leadership in Ghana. In T. R. Lituchy, B. L. Galperin, \& B. J. Punnett, Leadership Effectiveness in African and Diaspora. LEAD: Leadership Effectiveness in Africa and the African Diaspora. London: Palgrave McMillan.

Chukwu, B., \& Eluka, J. 2013. Theories in Nigerian Business Organisation. European Journal of Business and Management, 5(17): 166-171.

Hassan, A. R. 2009. Barriers to the Career Advancement of Women to top Management Positions in Lagos, Nigeria. $\mathrm{PhD}$ thesis submitted to the department pf Business Administration and Management Technology, Lagos State University, Ojo, Nigeria, April.

Hassan, A. R., \& Lituchy, T R. 2017. Leadership in Nigeria. In T. R. Lituchy, B. L. Galperin, \& B. J. Punnett, Leadership Effectiveness in African and Diaspora. LEAD: Leadership Effectiveness in Africa and the African Diaspora. Palgrave McMillan.

Hofstede, G. 2015. What about Nigeria? The Hofstede Centre. Retrieved from www.geert-hofstede.com/nigeria.htm/ 8/06/16

Hofstede, G., Hofstede, G. J., \& Minkov, M. 2010. Cultures and Organizations: Software of the Mind (3rd edn). New York: McGraw-Hill.

Hofstede, G. 2001. Culture's Consequences: Comparing Values, Behaviors, Institutions and Organizations across Nations (2nd edn). Thousand Oaks, CA: Sage.

House, R. J., Hanges, P. J., Javidan, M., Dorfman, P. W. \& Gupta, V. (Eds). 2004. Culture, Leadership, and Organizations: The GLOBE Study of 62 Societies. Thousand Oaks, CA: Sage.

Ogbeidi, M. M. 2012. Political leadership and corruption in Nigeria Since 1960: A socio-economic analysis. Journal of Nigerian Studies, 1 (2): 1-25.

Olojede, I. 2004. Public policy and gender politics in Nigeria. In O. S. Akinboye (Ed.), Paradox of gender equality in Nigerian politics. Lagos: Concept Publications Limited.

Suleiman, S. H. 2010. Statement. Paper presented at the 54th session of the commission on the status of women review conference, March 3, New York.

Zoogah, D. B., \& Beugré, C. D. 2013. Managing organizational behavior in the African context. New York: Routledge.
Cynthia A. Bulley (ayorkorb@hotmail.com) is a Senior Lecturer in Marketing and Organizational Research with the Central University, Ghana. She has had a varied career in industry and academia. She has facilitated workshops and training program for organizations in Ghana. Her considerable research, teaching and consulting activities focus on the application of marketing practices and organization capacity building. She is interested in experiential marketing, organizational management, and international business.

Noble 0sei-Bonsu (nobleosei.bonsu2014@gmail.com) is a highly self-motivated individual and team player. He holds an M.Phil. in Psychology, University of Ghana, Legon, with a specialization in Industrial and Organizational Psychology. Currently, he is a member of the Department of Human Resource Management, Central Business School, Ghana. His research interests include organizational change management specifically downsizing, organizational justice and career guidance.

Hassan Adedoyin Rasaq (doyinhassan3069@gmail.com) is an Associate Professor of Marketing, Lagos State University (LSU). He holds a Ph.D., LSU. He received the Best Paper Award for 'Inhibitive factor facing Women Managers in Lagos, Nigeria' at IAABD in 2011. He is an Associate Member of the National Institute of Marketing Nigeria and a Senior Member of the Academy of World Business and Management Development. He has published in over 40 journals and books. 